\title{
Teaching International Relations in a Changing World: Four Approaches*
}

\author{
Arie M. Kacowicz, Hebrew University of Jerusalem
}

\begin{abstract}
Since the late 1980s, teaching an introductory course of international relations has become a challenging assignment, given the rapid changes that have occurred in international relations in the last few years. The way instruction lags behind the realities of our international environment might have serious implications for the research agenda of international studies toward the 21 st century.

As a teaching assistant, I have had the opportunity to compare four different approaches to the study of intenational relations in introductory courses taught at the undergraduate level between 1984 and 1991 and to observe student reactions and how well the courses adapted to changing situations in the real world. I have labelled the four approaches assessed here as the "building-blocks" approach, the "comprehensive" approach, the "epistemology" approach, and the "paradigmatic" approach.
\end{abstract}

\section{Description of the Four Approaches}

\section{The Building-Blocks Approach: Theories and Approaches in International Relations Research (Professor Yaacov Y. I. Vertzberger)}

This was a second-year introductory course taught at the department of international relations of the Hebrew University, Jerusalem. The course followed the first-year "Introduction to Theories of International Relations," and formed part of the core three-year undergraduate program, which included two courses in diplomatic history from 1870 to the present, an introductory course on philosophy of international relations and world order, and a course on international law and international organizations. The course curriculum assumed that the students had learned the basic analytical concepts of international relations in their first year (e.g., levels of analysis, political Realism, power and influence, national goals and national interests, means and ends of foreign policy, decision-making approaches, the international system, and world order). Since the department of international relations offered parallel courses in diplomatic history and in international law, the course allowed for a higher degree of specialization and detail in the areas of theory and methodology, as compared to other introductory courses in international relations.

The course included 26 lectures (once per week throughout the academic year), and 13 discussion group sessions (every other week). Each week a different theoretical buildingblock was added to the analytical structure of the course. The lectures covered four main sections: (1) the actors in the international system (the state, international alliances, international organizations, and transnational actors); (2) interactions among actors in the international system (linkage politics, status and national roles, international communications, international guarantees and commitments, international conflicts and conflict management, bargaining and negotiation); (3) main processes in the international system (integration and disintegration, international political economy, technological changes, interdependence, international regimes, continuity and change in the international system); and (4) research methods and approaches (traditional and scientific methods, case studies and comparative methods, content analysis and event data, forecasting, and theory and policy making).

As a teaching assistant, I was responsible for the discussion sessions, in which a certain theory or analytical concept was applied in a particular historical or contemporary case. In these sessions, the students had the chance to analyze the abstractions from the lectures and reading assignments in a more tangible and concrete manner. For example, we discussed the theory of alliances with reference to NATO and the Berlin Crisis of 1961, or in the context of the Warsaw Pact and the invasion of Czechoslovakia in 1968.

\section{The Comprehensive Approach: Introduction to International Relations (Princeton, Spring 1989. Professor Steve Walt)}

Politics 240 is designed as the only introductory course to international relations for first-year students who do not necessarily major in politics at Princeton University. In addition, the department of politics offers a variety of courses in international relations for sophomores, juniors, and seniors, including American Foreign Policy, The Great Powers in International Politics, International Legal Order, International Organizations, Theories of International Relations, Introduction to World Order, the Soviet Union in World Affairs, War and Peace in the Nuclear Age, and Chinese Foreign Policy. Yet, the three versions of Politics 240 in which I worked at Princeton had to encompass, in a one-term course, fragments of what is offered in four different introductory courses in four terms at the Hebrew University (two in theories and two in international history). The results of this abridging effort varied from instructor to instructor, according to personal interest and research. For instance, in the case of Steve Walt, his course offered a general overview of different historical and theoretical themes in international relations with an emphasis on international security studies, which I labelled as the comprehensive approach.

In terms of dynamics, the course was divided into 23 lectures (twice per week) throughout the term, and weekly discussion groups (preceptorial discussions). The lectures were clustered into four main sections: (1) 
What is international relations?: Tools for analysis (international anarchy and the security dilemma, alliances and the balance of power, and domestic politics and misperceptions); (2) the politics of force and diplomacy (the First World War and the Cold War); (3) the politics of international economic relations (the transformation of global economic relations, North-North relations, North-South relations, and economics and security); and (4) current problems and future prospects (the Middle East, U.S. grand strategy, human rights and morality, the problem of nuclear weapons, and alternative future worlds).

In my role as preceptor, I led three weekly discussion groups in which we discussed the lectures and the readings, and speculated about issues such as the relevance of World War I and the Cold War for the understanding of international relations, the role of the United States in the current international economic system, the prospects for peace in the Middle East, and the moral dilemmas surrounding nuclear weapons.

The Epistemology Approach: Introduction to International Relations (Princeton, Fall 1989, Professor Roy Licklider)

This second version of Politics 240 , taught by Roy Licklider, a visiting professor from Rutgers University, was qualitatively different from Walt's comprehensive approach. Licklider's perspective was driven by a strong methodological and epistemological concern with the scientific approach; thus, I labelled his course as the epistemology approach.

The course included 24 lectures (twice per week) throughout the term, weekly discussion groups (preceptorial discussions), and two simulations of international systems and decision-making processes. The lectures were grouped into four sections: (1) science and wisdom; (2) international systems perspective (the concept of system and the international system, and international law and the international system); (3) foreign policy: choosing ends and means (national goals and the national interest, the concept of power, morality and foreign policy, and decision making); and (4) global issues (thermonuclear war and its alternatives, development and modernization, population, and food problems in the Third World).

As a preceptor, I led five weekly discussion groups in which we discussed the lectures, the readings, the four assigned papers, and the two simulations. In these precepts, I put particular emphasis upon illustrating and translating the methodological and theoretical concepts learned in the lectures into "real life," through historical and contemporary examples.

\section{The Paradigmatic Approach:} Introduction to International Relations (Princeton, Spring 1991, Professor Barbara Farnham)

This third version of Politics 240 , taught by Barbara Farnham, a visiting professor from Columbia University, differed from both Walt's and Licklider's approaches. Farnham sought to emphasize the study of international relations in terms of two conflicting paradigms: conflict versus cooperation, or force and power versus interdependence. Thus, I labelled her course as the paradigmatic approach.

The course consisted of 22 lectures (twice per week), a film on decisionmaking crises (which replaced a lecture on the subject), and weekly discussion groups (preceptorial discussions). The lectures included five main sections: (1) the subject of international politics (the nature and the study of international politics); (2) the international system (the evolution of the state system, levels of analysis and alternative explanations, the nature of the international environment, and mitigating anarchy: balance of power and concert); (3) foreign policy: the parameters of choice (explaining foreign policy, and ends and means of foreign policy); (4) force and interdependence in the international system (the role of force in historical perspective, the use of force in the nuclear age, force and interdependence, international institutions, interdependence and the international political economy, and interdependence and the environment); and (5) alternative futures. As a preceptor, I conducted five weekly discussion groups in which we discussed the lectures and the readings, while addressing contemporary issues of power and interdependence.

\section{Comparison and Assessment}

In order to compare the four approaches, we can establish a first distinction between the theoretical and the historical dimensions of the different courses. Furthermore, in a second cut, we might differentiate the different subfields of the discipline covered in the curricula (such as international law and organizations, methodology, foreign policy, international security studies, and international political economy). The results are summarized in Table 1.

From the reading of Table 1, we might draw the following conclusions:

(1) In contrast to "Theories and Approaches in International Relations Research"' (Professor Vertzberger), all three versions of Politics 240 at Princeton incorporated several lectures on international history. In the case of the building-blocks approach adopted at the Hebrew University, the existence of a simultaneous introductory course in diplomatic history allowed Vertzberger to focus almost exclusively upon theory and methodology. In addition, the discussion groups at Jerusalem were designed to apply the theories in specific historical and contemporary case studies, therefore bridging the gap between theory and history, instead of discussing the material from the lectures and the readings as in the preceptorial discussions at Princeton. Among the three versions of Politics 240 reviewed, Walt's comprehensive approach included 10 lectures on international history out of 23, while Licklider's epistemology approach involved only two, and Farnham's paradigmatic approach a total of four.

(2) In general, the subfield of international law and international organizations was neglected in all four approaches. The curricula did not consider extensively the renaissance of the United Nations and other international organizations in the last few years. In addition, issues concerning the Third World were 


\begin{tabular}{|c|c|c|c|c|}
\hline \multicolumn{5}{|c|}{$\begin{array}{l}\text { TABLE } 1 \\
\text { Comparing the Four Approaches }\end{array}$} \\
\hline \multirow[b]{2}{*}{$\begin{array}{l}\text { Categories } \\
\text { According to Subfields }\end{array}$} & \multicolumn{4}{|c|}{ Number of Lectures per Course and Percentage } \\
\hline & $\begin{array}{l}\text { (1) } \\
\text { Building Blocks } \\
\text { Approach }\end{array}$ & $\begin{array}{l}\text { (2) } \\
\text { Comprehensive } \\
\text { Approach }\end{array}$ & $\begin{array}{l}\text { (3) } \\
\text { Epistemology } \\
\text { Approach }\end{array}$ & $\begin{array}{c}\text { (4) } \\
\text { Paradigmatic } \\
\text { Approach }\end{array}$ \\
\hline Theory & $\begin{array}{c}26 \\
(100 \%)\end{array}$ & $\begin{array}{c}13 \\
(56 \%)\end{array}$ & $\begin{array}{c}22 \\
(92 \%)\end{array}$ & $\begin{array}{c}19 \\
(83 \%)\end{array}$ \\
\hline History & - & $\begin{array}{c}10 \\
(44 \%)\end{array}$ & $\begin{array}{c}2 \\
(8 \%)\end{array}$ & $\begin{array}{c}4 \\
(17 \%)\end{array}$ \\
\hline TOTAL & $\begin{array}{c}26 \\
(100 \%)\end{array}$ & $\begin{array}{c}23 \\
(100 \%)\end{array}$ & $\begin{array}{c}24 \\
(100 \%)\end{array}$ & $\begin{array}{c}23 \\
(100 \%)\end{array}$ \\
\hline $\begin{array}{l}\text { International Law } \\
\text { and IOs }\end{array}$ & $\begin{array}{c}1 \\
(3.8 \%)\end{array}$ & - & $\begin{array}{c}1 \\
(4.2 \%)\end{array}$ & $\begin{array}{c}1 \\
(4.3 \%)\end{array}$ \\
\hline Methodology & $\begin{array}{c}6 \\
(23 \%)\end{array}$ & $\begin{array}{c}1 \\
(4.3 \%)\end{array}$ & $\begin{array}{c}7 \\
(29 \%)\end{array}$ & $\begin{array}{c}1 \\
(4.3 \%)\end{array}$ \\
\hline Foreign Policy & $\begin{array}{c}2 \\
(7.7 \%)\end{array}$ & $\begin{array}{c}1 \\
(4.3 \%)\end{array}$ & $(16.6 \%)$ & $\begin{array}{c}3 \\
(13 \%)\end{array}$ \\
\hline $\begin{array}{l}\text { Security and Peace } \\
\text { Studies }\end{array}$ & $\begin{array}{c}4 \\
(15.5 \%)\end{array}$ & $\begin{array}{c}15 \\
(65 \%)\end{array}$ & $\begin{array}{c}8 \\
(33.6 \%)\end{array}$ & $\begin{array}{c}12 \\
(52 \%)\end{array}$ \\
\hline IPE and Global Issues & $\begin{array}{c}13 \\
(50 \%)\end{array}$ & $\begin{array}{c}6 \\
(26 \%)\end{array}$ & $\begin{array}{c}4 \\
(16.6 \%)\end{array}$ & $\begin{array}{c}6 \\
(26 \%)\end{array}$ \\
\hline TOTAL & 26 & 23 & 24 & 23 \\
\hline
\end{tabular}

generally ignored or understudied (the exception being Licklider, with four lectures addressing the problems of modernization, food, and population in the Third World).

(3) The curricula displayed in Table 1 show a preference for traditional or "high-politics" international relations over international political economy and global issues. Only at the Hebrew University, against the background of two year-long introductory courses in international relations theory, 13 lectures covered issues of international political economy and "low politics." Among the three versions of Politics 240, the number of lectures on international political economy was similar-four in the comprehensive and paradigmatic approaches, and only one in the epistemology approach. Regarding global issues such as ecological problems, human rights, and future world orders, the result was similar: one lecture in Walt's comprehensive approach (on human rights and morality); one lecture in Farnham's paradigmatic approach (on interdependence and environment); and three lectures in Licklider's epistemology approach (on population, food, and world food problems).

(4) In terms of method and approach, there is a clear contrast between the methodological concerns of the building-blocks and epistemology approaches, as opposed to the benign neglect of the comprehensive and paradigmatic approaches-the only lectures of the latter two on the subject focused on the level-ofanalysis problem.

\section{The "Demand" Side: Students' Expectations and Reactions}

From the vantage point of an assistant in instruction it is important to compare these four approaches from the demand side: What did students expect, and what did they want from an introductory course in international relations? What were their reactions?

(1) Students' Expectations. In this regard, a clear distinction should be drawn between the second-year students at the Hebrew University and the first-year students at Princeton. At Jerusalem, students were familiar with the scientific jargon and the different dimensions of the discipline. Though second-year students were trained in the basic concepts and theories of international relations in their first year, they were nevertheless puzzled and in some cases confused by the analytical abstractions and logic of theories designed to explain the world. They preferred to focus on more tangible and concrete issues, and felt at ease when those theories were applied in historical and contemporary cases. As compared with American students, Israeli students had a better sense of history and geography.

In contrast to the Israeli students, freshmen at Princeton who took Politics 240 were tabula rasa in intellectual terms, posing a constant challenge to any instructor and TA in international relations. They lacked significant geographical and historical knowledge about the world beyond the limits of the United States. At the same time, they were eager to understand the role of the United States in the world, especially in this period of turmoil in international politics. Moreover, since they had never been exposed to the theoretical intricacies and scientific language of our discipline, they were surprisingly refreshing and original in their discussion. They had not been spoiled by arid methodological and taxonomical debates and were able to rely on their (good) common sense. As with the Israeli students, Princeton freshmen preferred to address current events and expected to discuss contemporary issues such as the end of the Cold War, the Persian Gulf War, or Japanese-American trade relations. Unlike the Israeli students, the American students were particularly eager to engage in moral debates, and they were concerned with the role of the United States in the post-Cold War era. The end of the Cold War and the decline of the Soviet Union (the "official" enemy for the last 40 years) have dislocated their frames of reference but not their interest in international politics. Yet, there was an obvious gap between their expectations and the curricula that was offered.

(2) Students' evaluations of the four approaches. Students tended to be very critical in their evaluations, especially when doing so anonymously or off-the-record. In general, I found that students always complained, whether their grievances were justified or not. Regarding the 
four approaches reviewed in this paper, my students suggested several criticisms.

The building-blocks approach. This approach was considered by the students to be too rigid and too abstract. In addition, students complained that there were so many building-blocks in this course that they could not appreciate the entire structure of the theoretical edifice. In their view, the links among the different theoretical subjects had to be clarified and spelled out; otherwise, they felt lost in the weekly logical and theoretical abstractions of the lectures.

The comprehensive approach. Students seemed to enjoy this formula of combining history and theory in a quick and fast-paced overview. This was a fairly popular approach among the student population. The few complaints that arose referred to the idiosyncratic selection of the material covered in the course (Why World War I but not World War II? Why the Arab-Israeli conflict rather than the Indo-Pakistani conflict?).

The epistemology approach. Students disliked the focus on methodology adopted in this course. They regarded the course material as too abstract and detached from reality, and expected a more comprehensive and concrete discussion of international problems. At the same time, students found the course too easy and enjoyed the fact that they were released from mid-term and final exams, though they had some difficulty in adapting to creative writing in their four required papers.

The paradigmatic approach. In contrast to the first and third approaches, students protested the relative facility with which they digested the material from the lectures and the readings. Students were not satisfied with the study of international politics in a dichotomous way, and looked for further nuances in the analysis of contemporary issues.

\section{The ' 'Supply" Side: Teaching International Relations in the 1990s}

From the supply side of the discipline, the four approaches described above represent a sample of how different instructors teach introductory courses in international relations with different agendas and emphases. In this context, it is important to underline three different issues that should be addressed in the building of future curricula for similar courses: the problem of change in international relations, the opposition and juxtaposition of international security studies and international political economy, and the globalization of international relations.

(1) The problem of change in international relations. In general, the subject of change in international relations has been neglected because of an underlying tendency in the discipline to overemphasize stability and the status quo. This tendency is partly reflected in the four approaches reviewed, which did not address the problem of change in an extensive fashion (only one lecture in each of the approaches). Yet, as Robert Jervis suggests, "the current world situation is unprecedented" (Jervis 1991, 41). Regarding change, every year since 1987 has been characterized by eventful changes in international relations: 1988-the end of several regional conflicts in the Third World; 1989-the "peaceful revolutions" in Eastern Europe; 1990 -the reunification of Germany and the end of the Cold War; 1991-the Persian Gulf War and the dismemberment of the Soviet Union. In any introductory course to international relations there should be more room to address the theoretical and empirical dimensions of contemporary changes in international relations, including the discussion of alternative world orders, peaceful change, the end of the Cold War, the changing role of the United States in international politics after the Cold War, and the emergence of a multipolar world in terms of international political economy.

The opposition and juxtaposition between international security studies and international political economy. Over the past 20 years, international security studies and international political economy have developed independently of one another. This development is reflected in the four approaches reviewed, none of which integrated security and economic sub- jects in a meaningful way. As with the subject of change, the need for an integration between security studies and international political economy derives from the impact of the reality of international relations upon our academic work. Contemporary debates on the link between security and economics have a place in an introductory course of international relations, including the strategic implications of economic spending on defense by declining hegemonic powers, the emergence of the "trading state," and the explanation of cooperation under anarchy.

The globalization of international relations. The study and teaching of international relations are in turmoil in part because the reality of international politics has become turbulent. Indeed, some would argue that we are witnessing the dawn of "postinternational politics" (Rosenau $1990,3-20$ ). If that is the case, the teaching of international relations lags behind the reality of global politics. The traditional anarchical society of independent states has not been superseded in the early 1990 s by a supranational or subnational alternative; yet, it has been complemented by global processes and issues that transcend international relations. In other words, there is a growing need to teach both international politics and global politics in an introductory course of international relations.

\section{Conclusions}

It is easier to review four different approaches about teaching international relations than it is to come up with the ideal curriculum that would incorporate all the relevant issues for the study of international politics in the 1990s. Moreover, we should maneuver within the restricted framework of 23 to 26 lectures in a term or an academic year, keeping the students happy and satisfied and our senior colleagues puzzled by the dexterity and richness of our introductory courses.

Regrettably, there are no ideal formulae. One can only try to draw the lessons from the experiences of existing models, such as the four approaches reviewed in this article. Moreover, each introductory course 
should be assessed in its context, with reference to the other introductory courses offered at its department at the same time.

Drawing on these four approaches, I would like to offer the following suggestions about how to teach an introductory course of international relations in the early 1990s. In my view, the recipe for such a course should include $13 \%$ of the lectures (about three) on international law and international organizations (international organizations, international law, and world order, the evolving role of the United Nations); $13 \%$ of the lectures (about three) on methodology (traditional and scientific approaches, levels-of-analysis problem, philosophies and paradigms in international relations); $37 \%$ of the lectures (about nine) on international security and peace studies (including some historical background if it is not provided in a parallel course); and 37\% (about nine) of the lectures on international political economy and global issues. Furthermore, the approach should be eclectic, to the extent that the lectures should emphasize theoretical issues, while the discussion groups should debate historical and contemporary issues, in an effort to apply the basic concepts and theoretical tools learned in the lectures. In my opinion, a clear distinction should be established between international relations per se and foreign policy, and between levels of analysis and paradigmatic/philosophical approaches to international relations. Finally, international political economy and other global issues should get at least the same weight as the more traditional discussions of peace and war. To establish a logical link or thread among the different subjects and themes, two strategies might be followed: either through the different levels of analysis (first, second, and third images of international relations), or through the different philosophies or world-views of international relations (Realism, Liberalism, and Marxism). In this fashion, the instructor should also keep track of the contemporary changes in international relations, the globalization of international relations, and the integration of security and international economic studies. After all, the "menu for choice" of world politics is not restricted to the selection of the decision makers only. Since we bear the heavy responsibility of introducing our students to the academic world of international relations, we are entitled to choose as well, with the hope that our world resembles the real one sufficiently that it is also capable of affecting reality in a constructive way.

\section{Note}

*I would like to thank Yaacov Y. I. Vertzberger from the Hebrew University of Jerusalem, Steve Walt from the University of Chicago, Roy Licklider from Rutgers University, and Barbara Farnham from Columbia University for allowing me to use their course materials. I am grateful to Sammy Basu, Jacques Bertrand, and Roy Licklider for their comments and suggestions on a preliminary draft of this paper.

\section{References}

Jervis, R. 1991. "The Future of World Politics: Will It Resemble the Past?" International Security 16: 39-73.

Rosenau, J. N. 1990. Turbulence in World Politics: $A$ Theory of Change and Continuity. Princeton, NJ: Princeton University Press.

\section{About the Author}

Arie M. Kacowicz is an instructor, department of international relations, Hebrew University of Jerusalem. He obtained his Ph.D. from Princeton University in June 1992. His dissertation is entitled "Peaceful Territorial Change."

\title{
Easing the Transition: From Doctoral Student to Academic Professional
}

\author{
Beth M. Henschen, Loyola University of Chicago
}

While it is increasingly being recognized that most doctoral students receive little or no training to prepare them for assuming the role of faculty member, few graduate institutions have undertaken comprehensive programs designed to prepare tomorrow's professoriate. Typically, graduate education focuses on developing a student's substantive specialization and assumes that teaching competence and a sense of professionalism come with the awarding of the Ph.D. degree.
At Loyola University of Chicago, the graduate school has taken seriously the need to prepare doctoral students for the many roles they will play as academic professionals: teacher, researcher, departmental and institutional "citizen." Each year, 22 advanced doctoral students from nine departments are chosen on a competitive basis to participate in the Teaching Fellows Program. Fellows teach four courses (introductory and upper-level) during the year and attend weekly seminars that address issues of classroom effectiveness, research and publication, and professional obligation. Administrators and faculty members from a variety of disciplines speak to the fellows on topics such as strategies for leading classroom discussion, the art of lecturing, understanding the undergraduate, teaching critical thinking, presenting conference papers and publishing journal articles, writing grant proposals, the academic job interview process, legal issues confronting faculty, and ethical dimensions of the 